\title{
A rapid microwave method for isolation of genomic DNA and
}

3 Rao. Ramya G. ${ }^{1 \mathrm{a}}$, Ravichandran, $\mathrm{A}^{1 \mathrm{bb}}$., Dhali, $\mathrm{A}^{1}$., Kolte, A.P. ${ }^{2}$, Giridhar $\mathrm{K}^{3}$ and Sridhar

${ }^{a}$ PhD Student-Biochemistry Department, Jain University, Bengaluru, ${ }^{\mathrm{b}} \mathrm{DST}$ Women scientist, ${ }^{1}$ Bioenergetics and 


\section{ABSTRACT:}

White rot fungi (WRF) produce lignolytic enzymes comprised by laccases and peroxidases responsible for mineralization of recalcitrant lignin. Because of the so-called lignin modifying enzymes(LME's), these fungi have potential applications in biodegradation and bioremediation processes. Increased demand for lignolytic enzymes to exploit their various applications has sparked interest in identifying and characterizing new novel strains of WRF. Despite this undisputed biotechnological significance, molecular identification of WRF, remains a daunting task for researchers as genomic DNA isolation is a tedious process, unsuccessful many a times because of their rigid and resistant cell walls. A rapid, effective and efficient method to identify the innumerable fungal strains within no time is the need of the hour. The fungal mycelia of various unknown as well as know isolates of WRF, after alternative washing with TE buffer and sterile water were suspended in TE buffer. Fungi in solution were then exposed to microwave.

The crude extract contained genomic DNA which was extracted and amplified using ITS primers for further identification. Based on sequencing results the identity of known cultures was confirmed, while the unknown cultures were identified as Clitopilus scyphoides (AGUM004, BankIt2098576 MH172163); Ganoderma rasinaceum (AGUM007, BankIt2098576 MH172163);

Schizophyllum sp (KONA001 BankIt2098576 MH172164; AGUM011 BankIt2098576

MH172165and AGUM021 BankIt2098576 MH172166respectively), Coprinellus disseminatus (BANG001, BankIt2098576 MH172167) and Lentinus squarrosulus (TAMI004, BankIt2098576 MH172167). The microwave method described for isolating quality DNA of WRF without 
48 further purification steps proved a novel method requiring less than ten minutes and minimized

49 the chances of the presence of PCR inhibitors.

\section{IMPORTANCE:}

52 White rot fungi which decay wood, possess selective lignin degrading enzymes responsible for

53 degrading a wide variety of environmental pollutants, xenobiotic compounds in addition to

54 mineralizing chemicals that are insoluble and recalcitrant. Lignolytic enzymes hold potential

55 towards replacing conventional chemical processes and their increased demand in the market

56 has ignited interest in identifying and characterizing new strains of WRF. A rapid, efficient

57 method capable of quickly identifying fungal isolates is a constraint. The microwave method is a

58 novel quick method for isolating superior quality DNA. Its adoption circumvents the initial

59 purification steps and /or interference of PCR inhibitors, which are encompassed in the use of

60 conventional methods. The microwave method thus permits the thorough amplification of the

61 ITS region thereby aiding in the easy identification of unknown species. Use of the microwave

62 method will permit researchers to obtain DNA from fungi very quickly for further application in

63 molecular studies.

64 Key words: microwave method, genomic DNA, isolation, identification, white rot fungi

\section{INTRODUCTION:}

67 White rot fungi (WRF) are a group of fungi belonging to the Basidiomycetces which degrade the

68 lignin components from lignocellulosic substances causing bleaching of the wood [1]. WRF

69 produce the set of enzymes viz. Laccase (Lac), Manganese peroxidase (MnP), lignin peroxidase 
70 (LiP) and Versatile peroxidase (VP) which are responsible for the selective degradation of

71 recalcitrant lignin [ 2,3]. Because of this lignin modifying enzymes, WRF can degrade wide

72 varieties of environmental pollutants, xenobiotic compounds and also mineralize chemicals that

73 are insoluble and recalcitrant [4]. Hence, they have potential applications in biodegradation and

74 bioremediation processes. The ability of WRF to degrade lignocellulosic, a central aspect in

75 industrial uses of cellulosic biomass, such as bioethanol production, manufacture of cellulose

76 based chemicals and materials including paper and recently in crop residues as animal feed to

77 improve its nutritive value as they promise environmental friendly technologies [5,6]. Their

78 biotechnological significance has caused a drastic increase in the demand of these enzymes in the

79 recent few decades.

80 Limiting amounts of lignolytic enzymes however, are produced by WRF, and identification of

81 the produced enzymes impedes their commercial use in innumerable potential applications. The

82 species level identification of WRF (microorganisms), provides deeper insights on fungal life

83 cycle, evaluation and molecular aspects of the protein production which in turn helps researchers

84 to enhance the production of enzymes, identification of new species and meet the increased

85 demand [7]. On the other hand, we lack standardized protocols for conducting routine molecular

86 biology research of these microorganisms. Due to high polysaccharide contents, the cell walls of

87 WRF are rigid and are resistant to DNA extraction by traditional methods [8]. In addition,

88 methods involved in DNA isolation are laborious, tricky, time consuming and very expensive for

89 isolating DNA of excellent quality [9]. All these methods commonly employ the use of

90 detergents such as SDS for cell wall lysis, which often inhibits further purification manipulations

91 [10]. Most of these methods involve innumerable steps that take lot of time and in addition

92 possess the threat of contributing PCR inhibitors. 
93 In the present study, we report a simple and rapid method based on the application of microwave

94 for DNA isolation from some of the wild isolates of WRF which was then used for PCR

95 amplification and species identification of the unknown strains of WRF. This method has also

96 been compared with other easy and rapid methods being used for different fungal species by

97 researchers around the world. Qualitative and quantitative analysis of DNA extracted from

98 different methods was evaluated based on yield of DNA, purity in terms of A260/A280 ratio,

99 PCR and gel electrophoresis. Unknown WRF isolated were identified by sequencing the PCR

100 product of genomic DNA obtained from microwave method.

101 MATERIALS AND METHODS

102 Isolation and storage of WRF strains

103 Fruiting bodies or basidiocarps of WRF were collected in clean dry self- sealing polythene bags

104 from forest areas. Amongst the seven wild fungal isolates, KONA001was collected from 13.8048

$105{ }^{\circ} \mathrm{N}, 75.2530^{\circ} \mathrm{E}$; AGUM004, AGUM007, AGUM011 and AGUM021 were collected from

$10613.5187^{\circ} \mathrm{N}, 75.0905^{\circ} \mathrm{E}$; BANG001 was collected from $12.9470{ }^{\circ} \mathrm{N}, 77.6077^{\circ} \mathrm{E}$ while

107 TAMI004 was collected from location $08.9342^{\circ} \mathrm{N}, 77.2778^{\circ} \mathrm{E}$ from Karnataka, India. In all

108 cases the substrate was represented by wood found in various stages of decay. Pure cultures from

109 collected samples were obtained by tissue culture technique [11]. All pure cultures were

110 maintained on PDA slants and stored at $4{ }^{\circ} \mathrm{C}$ until further use. The cultures were marked with

111 information such as number and procurement location. Coriolus versicolor (MTCC138),

112 Ganoderma lucidium (MTCC1039) and Pleurotus sajorcaju (MTCC141) obtained from

113 Microbial Typing Culture Collection, Chandigarh, India were used as the reference cultures.

115 DNA extraction 
117 Four different methods were evaluated for the Extraction of DNA from the selected unknown 118 wild isolates of WRF:

119 Method 1: Rapid mini preparation of DNA

120 The rapid mini preparation of DNA [12] method was comprised of a small amount of revived

121 culture being suspended in $500 \mu \mathrm{L}$ of lysis buffer containing 400mM Tris-HCl (pH8), 60mM

122 EDTA(pH8), $1 \%$ Sodium dodecyl sulphate(SDS), $150 \mathrm{mM} \mathrm{NaCl}$ and the lumps disrupted using

123 sterile loop. Samples were incubated for 10 minutes at room temperature. The samples were

124 mixed with potassium acetate $(\mathrm{pH} 4.8)$ and centrifuged at $10000 \mathrm{Xg}$ for 2 min and the supernatant

125 in fresh Eppendorf spun again. Then the supernatant was mixed with an equal volume of

126 isopropyl alcohol by brief inversion. The sample was centrifuged for 2 minutes at 10,000Xg and

127 the supernatant was discarded. The pellet had DNA and was washed in $300 \mu \mathrm{L} 70 \%$ alcohol.

128 After the pellet was centrifuged for 1 minute at, the supernatant was discarded, and DNA was air 129 dried. The isolated DNA was then dissolved in $50 \mu 11 \mathrm{X}$ TE buffer $.1 \mu \mathrm{L}$ DNA suspension was 130 used for PCR.

132 In the thermolysis method [13] a small quantity of mycelia was picked by help of a sterile needle 133 from the fully-grown culture and transferred into $100 \mu \mathrm{L}$ sterile water in a $2 \mathrm{~mL}$ micro centrifuge tubes. The mixture was thoroughly vortexed and centrifuged at 10,000g for 1 minute.to the

135 pellet, after discarding supernatant $100 \mu 1$ lysis was added. The mixture was incubated at $85 \mathrm{C}$ in 136 a water bath for 25 minutes. The crude extract contained genomic DNA.1 $\mu 1$ supernatant was 137 used for PCR. 
Method 3: Microwave thermal shock method

As per the microwave thermal shock method [14] a small quantity of each of the revived cultures was suspended in $1 \mathrm{~mL}$ of washing solution containing $50 \mathrm{mmol} \mathrm{L}^{-1}$ Tris- $\mathrm{HCl}, \mathrm{pH} 7.7$, 25mmol L $\mathrm{m}^{-1}$ EDTA, $0.1 \%$ Sodium dodecyl sulphate (SDS), $0.1 \%$ polyvinylpyrrolidone (PVP). Samples were centrifuged at $6000 \mathrm{Xg}$ for $1 \mathrm{~min}$. and the pellets were resuspended in $35 \mu \mathrm{L}$ of lysis buffer containing 50mmol L $\mathrm{m}^{-1}$ Tris- $\mathrm{HCl}, \mathrm{pH} 8,25 \mathrm{mmol} \mathrm{L}^{-1}$ EDTA, 3\% SDS, $1.2 \%$ PVP. The mixture was then placed in a microwave oven (Electrolux EK30CBB6-MGZ; RF output- 900W) and heated at $700 \mathrm{~W}$ for $45 \mathrm{~s} .400 \mu \mathrm{l}$ of pre-warmed extraction solution containing $10 \mathrm{mmol} \mathrm{L}-1$ Tris $-\mathrm{HCl}$, $\mathrm{pH} 8,1 \mathrm{mmol} \mathrm{L}^{-1}$ EDTA, $0.3 \mathrm{~mol} \mathrm{~L}^{-1}$ Sodium acetate, $1.2 \%$ PVP were added to the microwaved sample. The DNA was extracted using phenol chloroform solution followed by isopropyl alcohol precipitation and $70 \%$ ethanol wash. Precipitated DNA was then resuspended in $100 \mu \mathrm{L}$ TE buffer ( $\mathrm{pH} 8.0)$. One $\mu \mathrm{L}$ buffer was used for PCR.

\section{Method 4: Microwave method}

All the selected wild isolates were removed from storage and revived on PDA slants at $27 \pm 2^{\circ} \mathrm{C}$ for 7-10 days. A small amount of mycelium from the grown culture was picked with the help of a sterile needle and transferred into $1000 \mu \mathrm{L}$ of $1 \mathrm{XTE}$ in $2 \mathrm{~mL}$ micro centrifuge tubes. The mixture was thoroughly vortexed and centrifuged at $10,000 \mathrm{Xg}$ for $1 \mathrm{~min}$. The supernatant was discarded, and the pellet was washed with $1000 \mu \mathrm{L}$ of 1 XTE again followed by with $1000 \mu l$ of sterile water. After the wash, pellet obtained was resuspended in $200 \mu$ of 1XTE. The mixture was then placed in a microwave oven (Electrolux EK30CBB6-MGZ; RF output- 900W) and heated at $900 \mathrm{~W}$ for 1 min. twice. The crude extract contained genomic DNA. $1 \mu 1$ supernatant was used for PCR. 
160 The quality and quantity of all isolated DNA was checked using a Nano drop (Thermo

161 Scientific) in terms of A260/A280 ratio and $\eta g / \mu L$ respectively [15].

162

163

164

165

166

167

168

169

170

171 bromide.

172 The PCR products of the seven unknown cultures KONA001, AGUM004, AGUM007,

173 AGUM011, AGUM021, BANG001, TAMI004 and MTCC culture MTCC138 were given for

174 sequencing. Sequences obtained from Eurofins India were aligned against EMBL DNA database.

175 All sequences were then checked against Gene bank with the help of BLAST. Culture names

176 were assigned based on more than $99 \%$ sequence similarity [18].
178

179

180

181

\section{Statistical Analysis}

ANOVA was performed to compare the different DNA isolation methods within each WRF isolate for DNA yield as well as purity. Mean and standard deviations were determined for replicates. For all the statistical analysis, software, SAS 9.3 was used. 


\section{RESULTS} BankIt2098576 MH172167).

The four different methods were used to extract DNA from 10 different WRF (KONA001, AGUM004, AGUM007, AGUM011, AGUM021, BANG001, TAMI004, MTCC138, MTCC1039, and MTCC149). The yields of DNA and quality of DNA, in terms of A260/A280 ratio, obtained from different methods are significantly different at confidence interval $99 \%$ (Table1). Concentration of DNA in case of method 4 is less than that of three methods 1,2 and 3. However quality is superior in case of DNA isolated from Method 4 as compared to the other three methods (Table 1). Concentrations of DNA and purity of DNA obtained by all the methods are in acceptable range for further molecular studies.

The PCR amplification and gel electrophoresis (Fig.1) reveals that using method 1and 2, only one sample each was got amplified and method 3, only two samples were amplified (Fig. 1 A, B and $\mathrm{C}$ respectively). Only DNA isolated for all the 10 samples from method 4 was subjected to amplification (Fig1 D). PCR products obtained with the help of method 4 for the seven unknown cultures and one MTCC culture Coriolus versicolor (MTCC138) were sequenced and were identified. The unknown cultures submitted to GenBank were identified as Clitopilus scyphoides (AGUM004, Bank It 2098576 MH172163); Ganoderma rasinaceum (AGUM007, BankIt2098576 MH172163); Schizophyllum sp (KONA001 Bank It 2098576 MH172164; AGUM011 BankIt 2098576 MH172165and AGUM021 BankIt2098576 MH172166respectively), Coprinellus disseminatus (BANG001, BankIt2098576 MH172167) and Lentinus squarrosulus (TAMI004, 
205 Though all the four methods used for isolating genomic DNA are capable of yielding DNA of

206 acceptable quality and quantity, only DNA obtained by help of the microwave method could get

207 amplified in PCR. The major reason behind the DNA not being amplified was the presence of

208 PCR inhibitors [19]. PCR may be inhibited by the presence of certain chemicals / biomolecules

209 released from fungal species which may vary from species to species, growth status and media

210 used for cultivation [20].

211 The microwave method offers several advantages. As this method takes less than 10 minutes to

212 isolate DNA bulk identification of WRF strains can be achieved very quickly saving precious

213 time by avoiding innumerable cumbersome steps as is in case of the other methods. Indeed, this

214 is the first report to isolate WRF genomic DNA by microwave method. In other protocols, a

215 microwave method was reported for bacterial genomic DNA [21, 22]. The DNA isolated does

216 not require chemicals like phenol or chloroform. This method also prevents the release of cell

217 wall chemicals of WRF and other chemicals released from the species which are known to be

218 potent PCR inhibitors. The yield of DNA and its purity is also in acceptable range and proven to

219 amplify ITS region and intern's species level identification.

220 The microwave method described here for WRF is a novel method that takes less than 10

221 minutes to isolate DNA without any initial purification steps and /or interference of PCR

222 inhibitors, permitting the amplification of the ITS region and thereby enabling the easy

223 identification of unknown species.

225 Future works need to be carried out in the direction of other molecular biology research with the

226 isolated DNA such as whether screening of genes of interest, cloning and expression in a

227 different host for increased yield of proteins/enzymes which are of commercial and clinical 
228 importance, phylogenetic tree construction etc., are possible. There is a possibility of using

229 Microwave method in environmental and biotechnological studies, because rapid DNA isolation

230 gives a simple solution to sequence several strains directly or by micro arrays [22].

\section{CONCLUSION}

232 The microwave method is a novel method taking less than ten minutes to isolate superior quality

233 DNA. Its adoption circumvents the initial purification steps and /or interference of PCR

234 inhibitors, which are encompassed in the use of conventional methods. The microwave method

235 thus permits the thorough amplification of the ITS region thereby aiding in the easy

236 identification of unknown species. Further work in the direction of supplemental molecular

237 biology research with the isolated DNA such as screening for genes of interest, cloning and 238 expression in a different host for increased yield of proteins/enzymes of commercial and clinical

239 importance, phylogenetic tree construction etc., are however warranted.

\section{CONFLICT OF INTEREST}

We certify that there is no conflict of interest with any financial organization regarding the material discussed in the manuscript.

\section{ACKNOWLEDGEMENT}

245 The financial assistance (GrantNo.BT/PR11205/AAQ/1/589/2014) provided by Department of

246 Biotechnology, (DBT), Government of India, New Delhi, is gratefully acknowledged by the

247 authors. The authors thank the Director, National Institute of Animal Nutrition \& Physiology, for

248 providing all the facilities for conduct of the research work. 


\section{Author contribution statement}

250 RRG executed this work. RA contributed to the design, AD and APK assisted in execution, and

251 analysis of this work. MS and GK contributed to the interpretation of results and drafting the

252 submission.

253

254

255

256

257

258

259

260

261

262

263

264

265

266

267

268

269

270

271 
272

273

274

275

276

277

278

279

280

281

282

283

284

285

286

287

288

289

290

291

292

293

294

\section{REFERENCES}

1. Goodell B, Qian Y, Jellison J, 2008. Fungal Decay of Wood: Soft Rot-Brown Rot-White Rot. Development of Commercial Wood Preservatives, 9-31. DOI:10.1021/bk-20080982.ch002.

2. Dashtban M, Schraft H, Syed TA, Qin W, 2010. Review Article Fungal biodegradation and enzymatic modification of lignin. Int $\mathbf{J}$ Biochem MolBiol 1(1):36-50. PMCID: PMC3180040 PMID: 21968746.

3. Ruiz-Duenas FJ, Morales M, Garcia E, Miki Y, Martinez MJ, Martinez AT, 2009.Substrate oxidation sites in versatile peroxidase and other basidiomycete peroxidases. J. Experimental Bot 60:441-452.

4. MendonçaMaciel MJ, Castro e Silva A, CamarãoTellesRibeiro H, 2010. Industrial and biotechnological applications of ligninolytic enzymes of the basidiomycota: A review. Electronic J Biotechnol, 13(6). DOI:10.2225/vol13-issue6-fulltext-2.

5. Sindhu R, Binod P, Pandey A, 2016.Biological pre-treatment of lignocellulosic biomassan overview. Bioresource technol, 99:76-82. https://doi.org/10.1016/j.biortech.2015.08.030

6. Rodríguez-Couto S, 2017. Industrial and environmental applications of white-rot fungi. Mycosphere 8(3) 456-466. doi 10.5943/mycosphere/8/3/7.

7. Raja HA, Miller AN, Pearce CJ, Oberlies NH, 2017. Fungal identification using molecular tools: A primer for the natural products research community. J. Nat. Prod.80:756-770 doi: 10.1021/acs.jnatprod.6b0185.

8. Moller EM, Bahnweg G, Sandermann H, Geiger HH, 1992.A simple and efficient protocol for isolation of high molecular weight DNA from filamentous fungi, fruit bodies, and infected plant tissue. Nucleic acids res, 20(22):6115-6116. 
9. Avin FA, Bassu S, Sabaratnam V, 2013.A simple and low-cost technique of DNA extraction from edible mushrooms examined by molecular phylogenetics. Res. on Crops 14 (3): 897-901.

10. Melo S, Pungatni C, Brendel M, 2006. Rapid and efficient protocol for DNA extraction and molecular identification of the basidiomycete Crinipellis perniciosa. Genetics Mol Res, 5 (4): 851-855.

11. Vidya PK, Naik C, Manpal S, 2013. Screening of white rot basidiomycetes for novel laccases. Adv App Res, 5(1): 84-89.

12. Liu D, Coloe S, Baird R, Pedersen J, 2000. Rapid Mini-Preparation of Fungal DNA for PCR.J Clin Microbiol., 38(1): 471.

13. Zhang YJ, Zhang S, Liu XZ, Wen HA, Wang M, 2010. A simple method of genomic DNA extraction suitable for analysis of bulk fungal strains. Letters Applied Microbiol, 51:114-118. Doi:10.1111/j.1472-765X.2010. 02867.xs.

14. Orsini M, Romano-spica V, 2001. A microwave-based method for nucleic acid isolation from environmental samples. Letters Applied microbiol, 33(1):17-20. Doi:10.1046/j Vis. Exp. 45(e2565) 1-4.DOI: 10.3791/2565 15. .1472-765X.2001.00938. x.

16. Desjardins P, Conklin D, 2010. Nanodrop Microvolume Quantitation of Nucleic Acids. J.

17. Toju H, Tanabe AS, Yamamoto S, Sato H, 2012. High-Coverage ITS Primers for the DNA-Based Identification of Ascomycetes and Basidiomycetes in Environmental Samples. PLoS ONE 7(7): e40863. doi: 10.1371/journal.pone.0040863.

18. Cenis JL, 1992. Rapid extraction of fungal DNA for PCR amplification. Nucleic Acids Res, 20(9):2380. 
19. Ferrer C, Colom F, Frasés S, Mullet E, Adad JL, Alió JL, 2001. Detection and identification of Fungal Pathogens by PCR and by ITS2 and 5.8S Ribosomal DNA Typing in Ocular Infections. Clin. Microbiol. 39 (8): 2873-2879.doi: 10.1128/ JCM.39.8.2873-2879.2001J.

20. Mot'ková P, Vytřasová J, 2011. Comparison of methods for isolating fungal DNA. Czech J. Food Sci. 29 (Special Issue): S76-S85.

21. Paterson, RRM, 2008. Fungal enzyme inhibitors as pharmaceuticals, toxins and scourge of PCR. Curr Enzyme Inhib., 4, 46-59.

22. Ahmed OB, Asghar AH, \&Elhassa M, 2014. Comparison of three DNA extraction methods for polymerase chain reaction (PCR) analysis of bacterial genomic DNA. African J Microbiol Res.8 (6):598-602.

23. Reyes-Escogido L, Balam-Chi M, Buenfil RI, Valdes J, Kameyama L, Martínez-Pérez F, 2010. Purification of bacterial genomic DNA in less than 20 min using chelex-100 microwave: Examples from strains of lactic acid bacteria isolated from soil samples. Antonie van Leeuwenhoek 98:465-74. 10.1007/s10482-010-9462-0. 
1 Table 1. Concentration (yield $(\eta g / \mu l)$ ) and Purity of DNA isolated from different WRF using 2 four methods

\section{DNA Yield $(\eta g / \mu l)$}

$\mathbf{A}_{260} / \mathbf{A}_{280}$ Ratio

WRF

\begin{tabular}{llllllll}
\hline Method1 & Method2 & Method3 & Method4 & Method1 & Method2 & Method3 & Method4
\end{tabular}

\begin{tabular}{|c|c|c|c|c|c|c|c|c|}
\hline MTCC138 & $66.9 \pm 1.29$ & $61.9 \pm 1.49$ & $64.9 \pm 0.58$ & $58.8 \pm 0.69$ & $1.93 \pm 0.02$ & $2.01 \pm 0.01$ & $1.93 \pm 0.03$ & $2.03 \pm 0.04$ \\
\hline MTCC149 & $110.7 \pm 1.52$ & $110.5 \pm 0.7$ & $114.5 \pm 1.8$ & $107 \pm 1.45$ & $2.09 \pm 0.07$ & $2.11 \pm 0.01$ & $2.11 \pm 0.04$ & $2.1 \pm 0.02$ \\
\hline MTCC1039 & $87.5 \pm 1.22$ & $84.3 \pm 1.37$ & $85 \pm 1.43$ & $79.6 \pm 0.78$ & $2.04 \pm 0.06$ & $2.05 \pm 0.02$ & $1.99 \pm 0.02$ & $2.03 \pm 0.05$ \\
\hline AGUM004 & $238.1 \pm 1.64$ & $226.3 \pm 3.71$ & $229.5 \pm 1.62$ & $227.5 \pm 0.93$ & $2.07 \pm 0.04$ & $2.1 \pm 0.02$ & $2.1 \pm 0.01$ & $2.06 \pm 0.07$ \\
\hline AGUM007 & $128.1 \pm 1.78$ & $120.9 \pm 1.2$ & $127.3 \pm 1.43$ & $126.5 \pm 1.58$ & $2 \pm 0.03$ & $2.04 \pm 0.03$ & $2.03 \pm 0.01$ & $2.04 \pm 0.04$ \\
\hline AGUM011 & $339.7 \pm 0.91$ & $334.8 \pm 2.52$ & $341.2 \pm 1.63$ & $338.6 \pm 0.77$ & $1.88 \pm 0.02$ & $1.88 \pm 0.04$ & $1.85 \pm 0.02$ & $1.88 \pm 0.04$ \\
\hline AGUM021 & $122.3 \pm 1.87$ & $126.5 \pm 2.18$ & $136.2 \pm 1.34$ & $119 \pm 1.43$ & $2.04 \pm 0.04$ & $2.03 \pm 0.03$ & $2.04 \pm 0.03$ & $2.06 \pm 0.06$ \\
\hline KONA001 & $152.8 \pm 2.62$ & $144.9 \pm 2.36$ & $159.7 \pm 1.23$ & $137 \pm 1.97$ & $1.92 \pm 0.02$ & $2.02 \pm 0.02$ & $1.95 \pm 0.02$ & $2.02 \pm 0.02$ \\
\hline BANG001 & $165.3 \pm 1.07$ & $147 \pm 2.31$ & $157.2 \pm 0.94$ & $142 \pm 1.46$ & $2 \pm 0.02$ & $2.09 \pm 0.03$ & $2.05 \pm 0.05$ & $2.05 \pm 0.04$ \\
\hline TAMI004 & $99.8 \pm 0.3$ & $94.4 \pm 1.35$ & $99.7 \pm 2.77$ & $93 \pm 0.95$ & $2.02 \pm 0.03$ & $2.07 \pm 0.01$ & $2.03 \pm 0.01$ & $2.05 \pm 0.04$ \\
\hline
\end{tabular}

3

4

5

6

7 


\section{Legend for Figures:}

2 Fig 1. Agarose gel electrophoresis images for PCR amplifications of ITS region of genomic DNA

3 of different WRF isolated using Method 1(A), Method 2(B), Method 3 (C) and Method 4

4 (D)Samples S1-10 are from WRF KONA001, AGUM004, AGUM007, AGUM011, AGUM021,

5 BANG001, TAMI004, MTCC138, MTCC149 and MTCC1039.Lanes for samples which were not

6 amplified are not shown in the gel images. 
bioRxiv preprint doi: https://doi.org/10.1101/307066; this version posted April 24, 2018. The copyright holder for this preprint (which was not certified by peer review) is the author/funder. All rights reserved. No reuse allowed without permission.

Fig 1

21

22

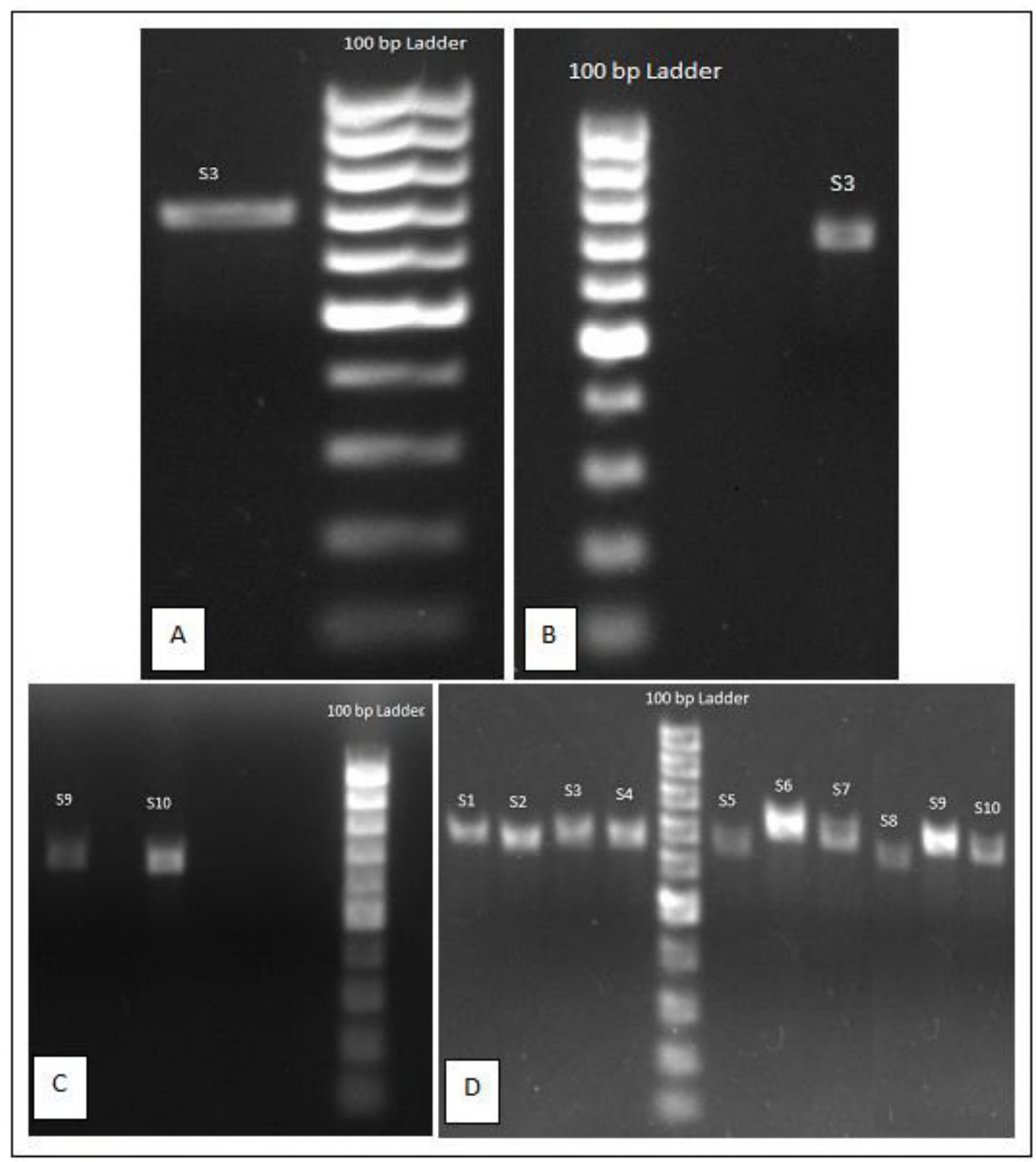

